\title{
THE STATE'S RESPONSIBILITY FOR THE LEGAL ORDER IN URBAN REGIONAL COMMUNITIES
}

\author{
JaMes C. N. PaUl $\dagger$
}

As Senator Clark has noted, the pace of our transition to a nation of metropolises seems to have outstripped, in significant ways, our collective capacity to cope with conditions which urban development is bringing. Yet, given a peaceful international community, I believe we have many basic opportunities to determine for ourselves more precisely what our destiny of living urban-oriented lives in these mushrooming metropolises may provide; to shape, through the legal order, urban development, not only in a purely physical sense, but in less tangible ways as well; to have communities which offer opportunity without discrimination to men of all walks, communities which offer openness and the beauty of nature, communities which offer adequate, efficient services, and communities which offer cultural richness and thus richness of life.

These tasks are of the essence, for our urban regions will reflect in microcosm, more and more intensely, both to our own consciences and to a critical world, what our country holds for men-our achievements and values, our cynicism and failures, the promise of our way.

As Senator Clark has shown, for many purposes an urban region is a single community. But it is also a combination of communitiesslums, staid suburbs, new suburbs, Republican strongholds, Democratic bastions-, variously interdependent, variously isolated from each other, and to some extent antagonistic to each other. Because the character and people of these communities differ in some ways as radically as Americans can; because there are, in a metropolis, many interests, many sovereigns, diverse political traditions, and opposing party organizations; because these and other pluralistic forces are at work, it is no easy task to discern the shared values of the region. It is no easy task to define the region's public interests, let alone secure them once defined. It is no easy task to obtain political leadership, founded on a broad base of consent, which will act towards these ends.

It may seem obvious that each resident of a metropolitan area has a legitimate stake in decisions which affect the future of the area

$\dagger$ Professor of Law and Director of the Institute of Legal Research, University of Pennsylvania. 
itself. But how can we get the people and the fragmented governments of urban regions to think, for some purposes, in terms of the interests and needs of the region qua region? How can we give adequate representation to the people and interests who are affected by decisions made by sovereignties which, because of their limited size and homogeneity, are immune to the concerns of others? It is this difficulty of defining and securing regional goals, consistently with our political structure, values, and habits, which, I think, epitomizes the challenge to the legal order we are talking about.

In broad terms, I believe the response must call for: (1) continued federal assistance through existing grant-in-aid programs, which can stimulate not only governmental action in doing things which must be done, but also intergovernmental cooperation and a regional orientation as well; (2) reorganization of local government to create democratically representative units with broader jurisdictions both in a geographic and governmental sense-the creation of strong and democratic suburban county governments is one possible line of direction; the creation of metropolitan government is another, but less likely in many places because it seems politically less palatable and thus improbable no matter how desirable; (3) a far more effective use of state government. It is this last point, calling for new departures in state government, which is my particular tocsin here.

I think state government is too often a neglected Cinderella when we talk of solutions to urban problems. Federal and local government, like the older sisters, command attention. There are some who seem to suggest that state government is largely illogical and irrelevant in heavily urbanized parts of our country. It may be suggested, for example, that the community of interests which bind the Penjerdel region are stronger for political purposes than those which may tie Philadelphia to Erie; that with most federal aid going directly to local government for many purposes, the state, for these purposes, might just as well follow Marx's edict and "wither away." There are some who may suggest that we must bypass the state as much as we can since its legislative constituency is geographically too big to be interested or competent to legislatate creatively on urban problems. Baker v. Carr ${ }^{1}$ notwithstanding, there will always be legislative power blocs from constituencies where, as the Senator has suggested, the birds and bees (in season) preponderate over voters. Those who will represent these places will care more about fish and game jurisprudence than the legal order in our urban community, and they will obstruct bills urgently needed by the metropolis. 
Needless to say, I disagree. I think we can, with the help of Baker v. Carr and governors and statewide political leaders who recognize that it is the aroused urban vote which counts, re-orient statehouse perspectives. It is simply unrealistic to ignore the responsibility of state government-which, constitutionally, is the creator and supervisor of local government-when we talk of metropolitan problems. I think our federal system can be made to work with new vitality. But it is time to abandon, in this field at least, classic concepts which see federal and state sovereignty competing for exclusive jurisdiction, when, in fact, they must be active partners. Federal programs generate state action and should create new opportunities for policy making by the states. Finally, I would insist that the state is inevitably involved, even if only through enacting passive enabling legislation, in the solution of metropolitan area problems.

Mention has been made of some tasks which are now commanding and getting attention, and where, more likely than not, the state's participation-with other units of government-as a policy maker and actor on the scene should be significant if not essential: water resources management, highway construction, development of regional park and open space areas, and air pollution.

There are other urban area problems, pressing I think, though they may command less attention since they deal with more intangible interests, with more idealistic values, or with conditions which affect many of us less immediately than do breakdowns in basic services or pollution of our air.

Urban poverty amidst urban affluence is the basis of some of these concerns; the gaps between our "have" and "have not" communities-which Senator Clark described-grow more stark as comfortable urban and suburban living becomes more and more an American way of life. These are not simply gaps between communities of the "old city" and the suburbs; census data show that there are serious slum pockets in many of our suburban communities as well, and many are receiving little if any attention. Racial discrimination, perhaps both a cause and an effect of some of these conditions, is becoming, partly because of the nature of changes the world over, more and more intolerable, especially in urban communities, and the signs of ugly trouble brewing in our cities are ever more apparent. The problem of slum schools, the fragmentation of school districts in many suburban areas, and the lack of clearer goals for and a more total regional commitment to education at all levels suggest more problems. 
The fragmentation of community planning and the pattern of our local land use controls are the basis of another set of concerns. Existing planning enabling legislation tends to be shot through with ambiguous abstractions and fuzzy mandates. On the regional level many urban communities still lack a planning process which will serve as a forum for the articulation of regional needs, provide representation of all affected citizens, and produce a plan to serve as a "constitution" or a framework for decision making by the region's component governments.

All this underscores the need, in my view, to move some sovereign powers of small local governments to higher governments. If we cannot have metropolitan government, we must at least have urban county government. That in itself is no mean task; but it is essential because in so many of our urban regions there is no meaningful forum, no democratically constituted government, to which those who may share many of the concerns I have noted can successfully appeal.

Time has permitted me only to suggest wherein some of the tasks of state government may lie. Even where the task is only to enact enabling legislation, it may still be a task where perceptive leadership must be exercised in our statehouses. Take, for example, planning and zoning enabling legislation; something is wrong-and all the blame cannot go on the courts-if we have no meaningful guides in our enabling legislation to tell us when or whether four-acre minimum lot zones in the suburbs are valid, let alone desirable regulations. And let me emphasize that many of the problems I have suggested are more or less inter-related. We should know by now that an effective attack on "gray areas" means not simply housing, but housing and welfare and education, all coordinated; and the state must play a critical role in framing, and to some extent administering, the legal order to deal with them.

If the challenges to state government are apparent, so are some of the difficulties in generating response. Rural domination of state legislatures may be a critical obstacle. And even if Baker v. Carr produces fairer reapportionments (which so far seems to be the case), this may not usher in the millenium in state legislatures. A hard look at some of the statistics where malapportionment actually exists will show that, in many states, the constituencies most likely to gain on reapportionment will be the suburban districts. If one judges by past experience, many suburban districts are not generating legislative representation which has evinced great concern over the urban area problems discussed here. This, I suspect, is also true of many suburban congressional districts. The indifference or intransigence of much 
of the suburban electorate-a phenomenon portrayed in studies like those of Robert Wood- ${ }^{2}$ is, I believe, another important explanation, at least in some states, for the failures or the weakness in the state response.

Nor has the traditional political behavior of officials and party leaders operating at the state level been closely attuned to the wave length of urban problems. Party leaders may simply be uninterested in the concerns voiced in this paper because they sense that discussing them in platforms and campaigns is not yet the way to elect candidates to the statehouse. Yet I think our parties, as they operate at the state level, may in fact be very important potential vehicles within which to mobilize forces to bring on the legislation which seems necessary. It is interesting to note that the national platforms of both parties are reflecting increasing concern and understanding of urban problems. Perhaps some of the precepts of the national parties will filter down and more effectively shape the thoughts of state political leaders.

Similarly, the arguments of nonpartisan groups, if focused more on state political leaders, may begin to tell. The growing importance of regional civic groups concerned with regional problems may help to evoke a new orientation. The Council of State Governments, and through it the Governor's Conference, has produced strong proposals for state legislation which reflect a new awareness of what it is that states must be doing. The voter himself-particularly the allimportant, fast-multiplying voter of suburbia-may finally begin to expand his perspective as a result of all the talk, alarums, study, and debate over urban problems.

Assuming we can find electoral leadership in the statehouse, I believe several steps are in order to make state government operate more creatively in the field of urban problems. First is the amendment or revision of state constitutions. While it is, perhaps, difficult to demonstrate, I believe the weaknesses which many state constitutions build into state government have a close nexus with the state's inertia. Like the threads of the men of Lilliput, I think the restrictions on debt, executive power, legislative power and procedure, taxation and legislative apportionment based on population, the provisions which tend to freeze the structure of local government, and many other provisions tend to tie state government down. The re-framing of state constitutions with an eye towards the role of the state in governing a nation of urban regional communities is a major task today.

2 Wood, Suburbia (1959). 
Second, I believe it is necessary to develop, within the executive branch of state government a department, headed by a man of cabinet stature, directly responsible to the governor, which will have responsibility for the formulation of policy and the administration of programs concerned with the very problems which have concerned us here. To a varying extent many states now have an office or department which serves local government. The Council of State Governments has recently proposed new legislation in this vein. But I believe executive leadership must be mobilized here in a grander manner; I would advocate a department vested with wide jurisdiction in the field of planning and community development, and, most important, charged with policy-making tasks. In this way, I believe, governors-and hence their legislative programs-may be involved more directly in urban affairs.

Finally, it is essential to strengthen our state legislatures with respect to their capacity to understand and deal with the problems of the urban community. The day of the part-time legislator is-or should be-over. Archaic restrictions on procedure, makeshift staffs, impotent committees, and the domination of the caucus are horse and buggy conditions which must be reformed to give legislatures the competence and eminence which the times now warrant.

Some may object because I have spoken for more government in the urban community, albeit for policy making through democratically constituted units, not proliferation of special-function autonomous agencies. It is ingrained in us that government is dangerous, that the least is best, that home rule should be the rule and departure from it the exception. Of course, there are risks as we expand government and remove power from town halls to county seats, the statehouse, or Washington. I do not discount them but, like Senator Clark, I believe there are greater risks in leaving to default, to private arrangements, or to belated ad hoc agencies the decisions which will shape tomorrow's legal order. 